\title{
O DEBATE AMERICANO SOBRE A CERTIFICACCÃO DOS PROFESSORES E A ARMADILHA DE UMA POLÍTICA EDUCATIVA “BASEADA NA EVIDÊNCIA"
}

\author{
THE AMERICAN DEBATE ON THE CERTIFICATION OF TEACHERS AND \\ THE TRAP OF AN EDUCATIONAL POLICY “BASED ON EVIDENCE”
}

\section{LE DÉBAT AMÉRICAIN SUR LA CERTIFICATION DES ENSEIGNANTS ET LE PIÈGE D’UNE POLITIQUE ÉDUCATIVE « EVIDENCE-BASED »}

\author{
EL DEBATE AMERICANO SOBRE LA CERTIFICACIÓN DE LOS \\ PROFESORES Y LA TRAMPA DE UNA POLÍTICA EDUCATIVA \\ "BASADA EN LA EVIDENCIA"
}

Claude Lessard *

\section{RESUMO}

Analisa-se o vivo debate, em curso no Governo Bush dos Estados Unidos da América, a respeito da certificação dos professores do ensino primário e secundário, que opõe os "profissionalistas" e os "desregulamentacionistas". Este debate é, ao mesmo tempo, ideológico, político e científico: num primeiro momento apresentam-se os protagonistas, as agendas que eles adotam, e o contexto de concorrência entre os grupos interessados no controle da politica educativa americana; num segundo momento, identificam-se os dados disponiveis e debatidos, as zonas de consenso e de discussão, assim como as estratégias de argumentação utilizadas para tentar vencer o "adversário" e "ser vitorioso". Enfim, em conclusão, reflete-se sobre as características do debate, notadamente sobre a referência à "política baseada na evidência" e sobre as ligaçôes que ela revela entre a ciência, a política e a ideologia.

Palavras-chave: Certificação. Desregulamentação. Formação do professor. Políticas públicas. Profissionalização do ensino. Universidade.

* Ph.D. en Théorie Éducationelle (1975). Professeur Titulaire de la Faculté des Sciences de l'Éducation de l'Université de Montréal - Canadá. Autor de livros publicados em seis países, entre eles: Tardif, M.; Lessard, C. O oficio de professor. História, perspectivas e desafios internacionais. Petrópolis: Vozes, 2008; Tardif, M.; Lessard, C. (2005). O trabalho docente. Elementos para uma teoria da docência como profissão de interações humanas. Petrópolis: Vozes, 4. ed., 2008; e Tardif, M.; Lessard, C.; Gauthier, C. Formação dos professores e contextos sociais. Porto - Portugal: Rés Editora, 2000 (claude.lessard@umontreal.ca).

Versão revista e ampliada do artigo publicado em francês na Revue des Sciences de l'Éducation, Montréal Canadá, v. 32, n. 1, p. 31-52, 2006. Tradução: Hélène Leblanc (hleblanc@terra.com.br). 


\section{INTRODUÇÃO}

$\mathrm{Na}$ luta pelo poder ao qual se submetem diversos grupos sociais constituídos, as ideologias abraçadas e defendidas sempre têm sua importância, porque elas permitem a cada um buscar transcender os interesses particulares e defender valores associados ao bem público. A ideologia sempre tem esse uso: ela facilita a passagem do particular ao geral, do mundo dos interesses ao domínio dos valores comuns, do singular ao universal. Para facilitar essa passagem, a ideologia incorpora a lista de argumentos, religando muitas vezes a análise de um determinado contexto social, das proposições de orientaçôes fundadas em valores explícitos e das justificaçôes de um programa específico. A ideologia combina assim regularmente ao mesmo tempo referências a "transcendentes" (a democracia, o desenvolvimento econômico, a justiça social etc.) e a análises e raciocínios estratégicos com ligação com uma realidade a ser salvaguardada, melhorada, ou a ser transformada. Nas sociedades contemporâneas, a ideologia incorpora quase sempre uma visão de futuro com relação à qual o presente é medido.

Nas sociedades modernas avançadas, a ideologia busca frequentemente apoiar-se na " ciência ", concebida como um dispositivo de produção de saberes sob a forma de resultados de pesquisa empiricamente " sólidos " e assim "incontestáveis", ou então sobre análises de contextos e de situações que se apresentam como "objetivas" e "racionais", ao mesmo tempo em que parecem sustentadas por um "senso comum". O texto que segue pretende ilustrar esta última afirmação, partindo de um caso preciso, ou seja, o debate atual nos Estados Unidos a respeito da certificação dos professores das escolas públicas. ${ }^{1}$ Esse debate reflete o enfrentamento de dois grupos que se dizem da ciência para melhor conduzir o seu combate ideológico e político. Mais precisamente, os dois grupos reconhecem a legitimidade de uma política educativa "baseada na evidência", isto é, uma política que "ajuda as pessoas a tomar decisões informadas a respeito de políticas, de programas e de projetos colocando no seio do desenvolvimento e da implantação das políticas a melhor pesquisa ("evidência") disponível" (DAVIES, 1999, p. 118). Uma abordagem do tipo "política baseada na evidência" implica que sejam ativados dispositivos de compilação da pesquisa existente, um conceito e indicadores de qualidade da pesquisa e uma compreensão ou uma interpretação do que a pesquisa "fala" ou "não fala". No caso das ciências humanas e sociais, isto está longe de ser evidente, não somente por causa das mediações ideológicas, mas também por causa da dificuldade dos consensos sobre os indicadores de qualidade da pesquisa e do caráter incerto e incompleto do saber das ciências sociais.

Neste texto, queremos então analisar o debate vivo, presentemente em curso nos Estados Unidos, a respeito da certificação dos professores do ensino primário e secundário. Ele opõe os que, de acordo com Cochran-Smith e Fries (2003), chamaremos os "profissionalistas" e os "desregulamentacionistas". Ele é ao mesmo tempo ideológico, político e científico. Ele é sustentado não somente por indivíduos (universitários, 
especialistas, quadro escolar ou homens políticos), mas também por fundações e institutos privados, para quem essa "causa" exemplifica um conjunto de questôes mais amplas, no seio do campo educativo e do conjunto da sociedade americana. Essas fundaçōes e institutos, há mais de duas décadas, têm uma agenda educativa explícita e têm mobilizado a sua expertise no debate público, notadamente na sua dimensão científica. Assim fazendo, têm contribuído consideravelmente para a estruturação das outras dimensōes, ideológicas e políticas.

O debate é cientifico, na medida em que ele coloca a questão do efeito do professor na aprendizagem dos alunos. Mais precisamente, ele coloca a questão do efeito da formação pedagógica e disciplinar dos professores sobre o sucesso dos alunos: segundo a fórmula americana mal traduzida em francês, mas mesmo assim corrente, "o professor faz uma diferença”? Se a resposta é sim, que fatores produzem esta diferença? Mas o debate transborda a ciência, notadamente procurando impor uma maneira um tanto reducionista de colocar esta questão e uma única metodologia para dar resposta.

O debate é também ideológico, tendo em vista que, mesmo compartilhando a mesma preocupação do bem público em educação, se opõem aqui dois modelos de qualidade do ensino: de um lado, um modelo profissional centrado numa formação universitária de longa duração dos professores, combinando uma formação disciplinar e uma formação pedagógica, organizada e vivenciada em alternância; e, de outro lado, um modelo descentralizado de quase-mercado educativo, de apresentação de contas e imputabilidade de professores e estabelecimentos. No primeiro modelo, uma verdadeira profissionalização é prevista, e uma parceria institucionalizada entre as universidades e as escolas com fins de formação clínica constitui um elemento central. No segundo modelo, a qualidade do ensino não é função dos atributos dos professores no momento de sua inserção na profissão; ela é mais uma função da obrigação de resultados imposta às escolas e aos seus administradores, da concorrência entre os estabelecimentos e dos programas de avaliação $\mathrm{da}$ aprendizagem dos alunos às consequências sérias ("testagem de alto risco").

Podemos também afirmar, sem enganar muito, que o debate opõe duas concepções de um professor de qualidade: de um lado, um professor dito "competente", e, de outro, um professor dito "eficaz". Não há como negar que, na verdade, esses dois modelos não devem se opor, porque esperamos que um professor competente seja eficaz nas suas intervenções. Assim como veremos mais tarde, essas duas concepçôes se opõem hoje em dia nos Estados Unidos; os partidários do ensino eficaz estimando secundárias as considerações de estatuto de professor, ao mesmo tempo um conjunto de elementos que eles associam aos "insumos" da educação, enquanto eles julgam da maior importância tudo o que contribui para uma valorização incondicional dos "produtos" ou dos resultados mensurados. Por oposição, os adeptos do ensino competente resistem mais ou menos a uma responsabilização que lhes parece excessiva dos professores e a uma concepção que lhes parece reducionista da missão do professor. Mas tudo leva a crer que 
estes últimos estão na defensiva, tentando limitar os avanços dos primeiros, muito conectados ao tempo político ideológico e a redes poderosas.

Enfim, o debate é político na medida em que os adeptos do segundo modelo buscam quebrar o "monopólio" das faculdades de educação em matéria de formação dos professores e dos acessos ao ensino. Eles propõem igualmente programas alternativos de formação, de vias múltiplas de certificação e de acesso à profissão. E eles queriam deslocar uma parte do poder da universidade em direção aos estabelecimentos e às direções das escolas.

Nós pretendemos neste texto analisar esse debate, num primeiro momento apresentando os protagonistas, as agendas que eles adotam, e o contexto de concorrência entre os grupos interessados no controle da política educativa americana. Num segundo momento, nós nos ateremos ao debate científico propriamente dito, identificando os dados disponíveis e debatidos, as zonas de consenso e de discussão, assim como as estratégias de argumentação utilizadas para tentar vencer o "adversário" e "ser vitorioso". Enfim, em conclusão, refletiremos sobre as características do debate, notadamente sobre a referência à "política baseada na evidência" e sobre as ligações que ela revela entre a ciência, a política e a ideologia.

\section{OS PROTAGONISTAS: AS FUNDAÇÕES FILANTRÓPICAS INFLUENTES, OS DOCENTES UNIVERSITÁRIOS E OS PESQUISADORES COMPROMETIDOS}

As fundações e os institutos privados constituem interfaces entre o político, o mundo do saber e os diversos universos de ação social. Historicamente, eles sustentaram as artes, bibliotecas e pesquisas. Eles adotaram causas, como o ensino público de qualidade, e, para os seus modos de trabalho e a qualidade de sua reflexão, eles contribuíram na influência sobre o estado, se não da opinião pública em geral, pelo menos daquela que conta em matéria de influência e de tomada de decisão. Ao longo das últimas décadas, eles têm utilizado frequentemente comissões como modo de trabalho privilegiado, isto é, um painel de especialistas universitários, de políticos e de representantes dos meios envolvidos de prática, a fim de formular um estado dos lugares relativamente consensual e uma agenda de reformas de forma a corrigir certas distorçóes e assegurar uma melhor adaptabilidade às realidades atuais e emergentes. Portanto, as fundações não somente produziram relatórios, estudos ou analises. Elas passaram à ação e se comprometeram em terrenos precisos. Por exemplo, C.E. Finn e D. Ravitch, da Fundação Fordham, colocaram em pé em 1981 uma rede de excelência (Rede de Excelência Educacional, REE), uma organização patrocinada pela fundação e centrada em reformas educativas "fundadas" ("sólidas") e na difusão de informações e idéias "válidas" aos propósitos da educação. Essa rede se caracteriza por uma vontade de elevar as exigências (ou "padrões") de formação e assegurar um forte conteúdo acadêmico, bem como pela aceitação de uma imputabilidade "pura e dura" ("prestação rigorosa de contas"). 
Nem todas as fundações e todos os institutos são idênticos. Basta consultar os enunciados de missão de diversas fundações e institutos para ver claramente suas orientações e posições políticas em geral, bem como em matéria de educação. Assim, em se apoiando sobre os princípios da liberdade individual, econômica e política, da liberdade de negócios e de governo representativo, a Instituição Hoover busca, "coletando conhecimento, gerando idéias e disseminando ambos, assegurar e salvaguardar a paz, melhorar a condição humana e limitar a intrusão do governo nas vidas dos indivíduos" (www.hoover.stanford.edu/main/mission.html, outubro de 2004). Do seu lado, a Fundação Fordham, na área de educação, pretende fazer avançar o conhecimento e a aceitação de estratégias educativas que incorporam os seguintes princípios: "a necessidade de padróes dramaticamente mais elevados; um sistema educacional desenhado e correspondendo às necessidades de seus usuários; resultados e prestação de contas verificáveis; igualdade de oportunidade; uma base curricular sólida ensinada por instrutores especialistas e cultos; diversidade educacional; competição e escolha" (www.edexcellence.net/foundation/global, outubro de 2004).

O debate que nos interessa opõe dois grupos de intelectuais universitários (alguns atores importantes das ciências da educação americana, por exemplo Linda DarlingHammond, ${ }^{2}$ outros mais ligados à cultura disciplinar universitária, por exemplo, Diane Ravitch $^{3}$ ), homens e mulheres políticos (governadores, membros dos dois grandes partidos nacionais, levando uma carreira nas instituições políticas federais ou nas instâncias políticas de vários estados ${ }^{4}$ ), do pessoal escolar (superintendentes e quadros superiores), homens de negócio, pesquisadores e analistas empregados das fundações envolvidas no combate. Dentro deste subgrupo, há economistas cuja especialização em avaliação das políticas públicas e em métodos quantitativas é importante no quadro analisado neste texto. Esses indivíduos, vindos de vários meios sociais, têm em comum pertencer a uma elite americana, ser formados nos melhores meios universitários e querer contribuir para a evolução da sociedade americana a partir de um ponto de vista explícito ou de uma "sensibilidade política" particular. Eles estão reagrupados, para otimizar a eficácia de sua ação, no meio de fundações filantrópicas privadas, algumas das quais são ricamente dotadas, enquanto vários deles desfrutam de um capital de influência não desprezível. É mais do que provável que os diversos subgrupos que participam das atividades das fundações e dos institutos tirem dali um real benefício: de idéias, de influência, de redes, de informação privilegiada, do reconhecimento, etc.

Esses subgrupos identificados com diversas fundaçoes e institutos não são herméticos uns com os outros: vários universitários envolvidos no debate têm, em uma ou outra etapa de sua carreira, deixado a universidade para ocupar cargos governamentais ou em conselhos de administração e escritórios de analise e pesquisa de prestigiosas fundaçôes. $\mathrm{O}$ caminho da carreira de Chester E. Finn é, neste aspecto, um exemplo 5 do vaivém entre o mundo universitário e o mundo político. Neste caso em apreço, o universo das fundações parece nitidamente funcional como interface entre os dois mundos. 
Ademais, se essas fundações são entidades distintas em grande parte por causa de sua história e da marca do fundador doador, elas apresentam elos umas com as outras, pelo menos entre as que compartilham "sensibilidades políticas comuns". Isto pode ser observado em particular na composição dos conselhos administrativos e dentro do grupo dos "associados seniores". É assim que Chester E. Finn é redator da revista Education Next, publicada pela Instituição Hoover, ao mesmo tempo em que é presidente e diretor geral da Fundação Fordham. Sra. Ravitch é, ao mesmo tempo, membro da Instituição Brookings e da Fundação Fordham. A revista "Education Next", porta-voz da agenda da desregulamentação, é sustentada, entre outros, pelo Instituto Manhattan (Nova Iorque), a Fundação Fordham e o Instituto Hoover. Existe então uma rede de pessoas e organismos que se reconhecem como compartilhando a mesma agenda ou tendo uma mesma visão política, ou seja, de interesses comuns.

Pareceria que a rede à direita do tabuleiro político seja mais imponente e mais bem dotada financeiramente que aquela à esquerda ou centro-esquerda. De fato, deste lado, a rede parece mais organizada a partir da universidade. Por exemplo, o Grupo Holmes reagrupou de início umas 50 faculdades de educação das universidades de boa reputação; foi animado por Judith Lanier, decana da faculdade das ciências de educação da Universidade do Estado de Michigan: esta participou nos trabalhos do grupo de trabalho sobre a profissão do ensino da Fundação Carnegie, cujo relatório Uma Nação Preparada (1986) constitui o fundamento da agenda da profissionalização do ensino nos Estados Unidos. Esse relatório foi seguido 10 anos mais tarde pelo trabalho da Comissão Nacional sobre Ensino e o Futuro da America (1996) sobre a formação dos professores, no qual participou L. Darling-Hammond e que foi sustentado pela Fundação Carnegie.

O estudo das fundações e dos institutos privados, enquanto interfaces, levanta muitas questōes. Entre essas, quatro são particularmente importantes: 1) Que agendas de reformas eles adotam? 2) Que saberes e que campos de conhecimento são pertinentes e merecem ser sustentados e desenvolvidos no quadro das fundaçóes e dos institutos na área das políticas públicas? 3) Quem são os especialistas produtores de análises e eventualmente de políticas que estruturam o debate público em educação? 4) Qual é o lugar da especialidade no debate público e no processo de tomada de decisão democrática? Nesse contexto, abordaremos as duas primeiras questões, a partir do caso em estudo, ou seja, da política americana a respeito da certificação dos professores do ensino primário e secundário.

\section{AS DUAS AGENDAS DE REFORMA:A DESREGULAMENTAÇÃO E A PROFISSIONALIZAÇÃO DA FORMAÇÃO DOS PROFESSORES}

Para os fins de nossa análise, importa nos atermos um pouco ao manifesto da Fundação Fordham com titulo "Os professores que precisamos e como termos mais deles: um manifesto" (1999). Esse manifesto foi assinado por umas 50 personalidades, entre C. E. Finn, D. Ravitch e muitos outros associados a várias fundações e institutos conservadores, 
como a Fundação Heritage, o Instituto Hudson, o Instituto Goldwater, o Instituto Pionner e o Instituto Manhattan. O manifesto retoma o elemento de base do diagnóstico escolar feito em 1983 pelo relatório Uma Nação em Risco: as escolas americanas têm baixo desempenho e o problema não será resolvido enquanto não houver em cada sala de aula excelentes professores. Segundo o manifesto, está claramente demonstrado que a mais importante variável na aprendizagem dos alunos é a qualidade do professor. E todas as reformas educativas fracassam porque elas são incapazes de garantir que mais e mais professores detenham o saber e as capacidades necessárias para ajudar todos os seus alunos a aprender. Sabemos que os professores "fazem uma diferença". O que importa saber, sustenta esse manifesto, é como formá-los, atraí-los, avaliá-los e retê-los no ensino. Ora, a formação dos professores americanos sofre sérias carências e não tem boa reputação, inclusive junto aos próprios professores; os professores são insuficientemente formados nas matérias que eles devem ensinar. Também não é possível atrair para a formação de professores estudantes que detêm excelentes históricos escolares ("o melhor e o mais brilhante") e o sistema parece ser incapaz de reter um número suficientemente elevado dos e das que estão entre os melhores estudantes. $\mathrm{O}$ atual sistema de formação, conclui o manifesto, é em suma incapaz de responder ao desafio duplo da qualidade e da quantidade.

A recente resposta de um certo número de Estados a esse duplo problema foi aumentar as exigências de certificação: mais aulas, testes estandardizados e estágios prolongados. Essa resposta, segundo o manifesto da Fundação Fordham, não pode ser eficaz, porque, do similar ao mesmo ("mais do mesmo"), ela reforça o status quo (isto é, o poder das faculdades de educação e dos burocratas), torna mais pesado, estandardizado e uniforme o sistema de certificação, impõe uma ortodoxia profissional mais perto das ideologias e das modas que os resultados sólidos de pesquisa, e é custosa, pois ela conduz, inevitavelmente, a um crescimento da escolaridade antes da inserção na profissão. Ademais, essa resposta não se justifica, porque a suposta base de conhecimento que fundamenta a pretensão das ciências da educação a assumir a responsabilidade pedagógica e prática da formação dos professores não é muito sólida (ela é “instável”). Além disso, quando ela existe num determinado setor, as escolas de formação de professores têm tendência a não tirar as consequências necessárias, já que isto lhes parece contrário à sua ideologia. $\mathrm{O}$ trecho seguinte do manifesto merece ser citado por inteiro, porque ele ilustra perfeitamente a crítica feita às ciências da educação americanas de serem "ideológicas" e pouco "científicas".

[...] há um consenso científico hoje, por exemplo, acerca dos métodos mais efetivos de ensino primário de leitura para crianças pequenas. Há evidências bastante fortes quanto à eficácia de pedagogias como a Instrução Direta. Mas a grande parte do conhecimento mais seguro e bem documentado sobre educação é ignorado, mesmo até denunciado, por muitos programas de formação de professores, enquanto a sabedoria popular que eles dão a conhecer aos novos professores - a respeito de métodos favoritos e reforço de auto-estima, por exemplo - tem pouco ou nenhuma base na pesquisa. Não é de se surpreender que pessoas desconfiem da formação de professores [...] uma ortodoxia que não funciona (1999, p. 6). 
Temos, então, de pensar em outra coisa, conforme a Fundação Fordham: "é chegada a hora de considerar políticas radicalmente diferentes para alçar a qualidade do ensino nas escolas nos Estados Unidos" (1999, p. 8). Esta outra abordagem não é fundada nem na ciência nem na ideologia; ela se apoia mais no senso comum. De fato, este nos diz que devemos desregulamentar a profissão do ensino, abrindo seu acesso a uma grande diversidade de candidatos, e permitir aos diretores dos estabelecimentos contratar e avaliar quem eles acham competentes. Então, trata-se de assegurar que essas escolas e seus administradores sejam responsáveis pelas suas decisões e especialmente pela aprendizagem e pelo sucesso dos alunos sob sua responsabilidade. Em suma, afirma o manifesto, mais liberdade para mais resultados.

Gestores em nível de escola estão na melhor posição para saber quem ensina bem e quem ensina mal. Eles têm acesso a informação bem mais significativa que os conselhos de autorização dos estados e agências governamentais. Eles devem ter o poder (e se for o caso, ser treinados) para avaliar o pacote singular de cada professor em termos de pontos fortes e fraquezas em vez de haver burocracias distantes que decidem quem deve fazer parte do seu time. Uma vez contratados, professores devem ser avaliados na única medida que realmente interessa: se seus alunos estão aprendendo (1999, p. 9).

Por cima, segundo o manifesto, o "senso comum" nos diz que se não existe uma maneira "infalível" de formar e de certificar os professores de qualidade, se não sabemos quais são as características dos professores que influenciam quais as aprendizagens dos alunos, então não podemos sustentar a manutenção de uma única via de acesso ao ensino, a saber os programas universitários "tradicionais" em ciências da educação. Temos de pôr fim a esse "monopólio" e dar lugar ao pluralismo, à experimentação de programas alternativos e que cada um seja submetido ao "teste do mercado". Em ambiente concorrencial desse tipo, os bons programas serão reconhecidos e terão sucesso; os outros desaparecerão, já que os encarregados dos estabelecimentos não contratarão os diplomados de programas julgados ruins.

O que se deve fazer, de acordo com esse "senso comum", é aparentemente simples e direto. Isto se baseia em quatro pontos:

1. Os Estados deveriam desenvolver sistemas de imputabilidade das escolas centrados nos resultados; esses sistemas deveriam ser voltados tanto para as escolas, como para os professores e alunos.

2. Os Estados deveriam autorizar as direçōes de escolas a tomar decisões em matéria de pessoal de ensino e de gestão de recursos humanos do estabelecimento sob sua responsabilidade.

3. Os Estados deveriam manter um mínimo de regulamentação de pessoal de ensino a fim de assegurar que, desde a entrada, os professores não pudessem causar prejuízo sério aos alunos: esta deveria incluir verificações de seu passado, a exigência de uma 
graduação (licenciatura) disciplinar, e exames impostos pelo Estado nas matérias de ensino.

4. Os Estados deveriam também abrir novas avenidas para o ensino, incitar a diversidade e a liberdade de escolha entre muitos dispositivos de preparação ao ensino, e acolher no ensino uma gama mais larga de pessoas talentosas e bem formadas desejosas de ensinar (mesmo que estas não sejam formadas em ciências da educação).

A referência a valores gerais tipicamente americanos é formulada de maneira eloquente nesta citação de C. E. Finn, na ocasião de um debate público que ele defendeu com L. Darling-Hammond no quadro de um encontro da comissão de educação dos estados, realizada na primavera de 2000 no Wyoming:

"Eu acho que o que este assunto (ensino de qualidade) precisa hoje, e alguns de vocês podem achar isto não característico de mim, é humildade, abertura de espírito, pluralismo e experimentalismo [...]. Isto não é um empreendimento que está amadurecido por dogmatismo, certeza, monopólio, ou políticas "um tamanho serve a todos". Este é um apelo à liberdade, delegação, pluralismo, e diversidade, todos centrados no conceito de prestação de contas da escola" (2000).

Sublinhamos nesse extrato o ataque explícito à posição do outro grupo, caracterizado pela dogmática e monopolística, ou seja, qualidades pretendidas pouco americanas. Enquanto a abertura de espírito, o pluralismo, a experimentação parecem ser valores tipicamente americanos.

A agenda de reforma dos "desregulamencionistas" foi parcialmente entendida pelo Secretário de Estado americano de Educação, Rod Paige. Este reconheceu publicamente que nada prova a eficácia das formaçôes de professores ditas "tradicionais". Ele concluiu que podia sustentar financeiramente o Centro Nacional para a Informação em Educação, um organismo recentemente implantado para assegurar a circulação da informação entre os responsáveis e os atores implicados em cerca de 120 programas alternativos de formação e de certificação dos professores atualmente ofertados nos Estados Unidos. Esse centro notadamente estende no seio da rede toda informação sobre as práticas de formação ditas eficazes (FEISTRITZER, 2004).

É claro que a administração americana atual sustenta a posição dos desregulamentacionistas. É só ler o relatório do Secretário da Educação com título "Encontrando o Desafio dos Professores Altamente Qualificados" (2002) para dissipar qualquer dúvida a esse respeito. De fato, na política presidencial Nenhuma criança deixada para trás (que agora tem força de lei), G. W. Bush assumiu compromisso de modo que cada classe americana seja ensinada por um professor "qualificado". A definição legal do governo federal do que seja um professor qualificado coloca o acento prioritário no conhecimento disciplinar. ${ }^{6}$ O Secretário da Educação tira as consequências dessa volta em força das disciplinas: a formação pedagógica, nos programas universitários em educação, deveria 
ser opcional, e programas alternativos, nascidos na urgência e para conter a penúria, deveriam ser daqui para frente soluçóes permanentes, adaptadas a um mercado de formação agora desregulamentado, sem monopólio universitário.

A agenda está também em fase de realização, enquanto participa do novo paradigma das políticas públicas em educação, o que coloca ênfase sobre a responsabilização dos estabelecimentos e dos atores locais na aprendizagem dos alunos, a obrigação de resultados e a imputabilidade dos atores locais.

De sua parte, a agenda da profissionalização do ensino é sustentada pela Corporação Carnegie e a Fundação Rockefeller de Nova Iorque, os Trustes Pew Charitables, a Fundação Ford e o Fundo DeWitt Wallace Reader's Digest (COCHRAN-SMITH; FRIES, 2001, p. 3). Essa agenda foi inicialmente problematizada, formulada e justificada em 1986 no Relatório A Nação Preparada: Professores para o Primeiro Vigésimo Século, financiado pela Corporação Carnegie de Nova Iorque, por intermédio de seu programa intitulado o Fórum da Carnegie sobre a educação e a economia.7 A agenda da profissionalização que ele propõe está em vias de realização, pelo menos em parte e em certos Estados e distritos escolares, graças aos esforços conjuntos do Conselho Nacional para a Validação da Educação de Professores (NCATE), revigorada a partir de 1991, o Conselho Nacional para os Padrões de Ensino Profissional (NBPTS), criado em 1987, e o Consórcio Interestadual de Avaliação e Apoio de Novos Professores (INTASC), também instalado em 1987.

Cabe também mencionar a Comissão Nacional sobre o Ensino e o Futuro da América, referente à formação dos professores, cujo relatório foi apresentado ao público em 1996 e que serviu de base à construção de parcerias entre uns 15 Estados e a Comissão Nacional sobre o Ensino e o Futuro dos Estados Unidos. Essas parcerias dizem respeito à análise da situação prevalecente no Estado em matéria de educação e sobre o sustento da comissão na formulação de políticas e estabelecimentos de programas de ação apropriados e adaptados às realidades identificadas e percebidas como problemáticas. A agenda está também em vias de realização nas universidades que, na onda dos relatórios do Grupo Holmes (LESSARD, 2003), buscam aperfeiçoar substancialmente os seus programas de formação de professores, realçando as exigências e os pisos de sucesso, alongando a formação (quatro ou cinco anos) e, em um número crescente de casos, criando mestrados em ensino e também implantando escolas de formação clínica (as Escolas de Desenvolvimento Profissional ou PDS).

A Comissão Nacional sobre o Ensino e o Futuro da America reuniu 26 pessoas vindas da área política, do meio dos negócios e do mundo da educação. Linda Darling-Hammond foi a secretária e diretora geral. É, portanto, ela a principal porta-voz até esta data. Depois de dois anos de trabalho, a comissão propôs cinco orientações assim formuladas de maneira imperativa:

1. Sejamos sérios a respeito das exigências ("padrōes"), tanto para os alunos quanto para os professores. Se desejamos elevar as aprendizagens dos alunos, é importante ter 
certeza que seus professores sejam capazes de ensinar sua matéria ao nível desejável de exigência.

2. Reinventamos a formação inicial e continuada dos professores. Trata-se de religar a formação clínica nas escolas com o saber disciplinar e pedagógico eficaz. É importante também assegurar um desenvolvimento profissional sustentado, rico em conteúdo e ancorado no currículo das escolas, em vez de ateliês desconectados e fundados numa abordagem do tipo "borrifa e reza".

3. Corrigimos o sistema de oferta e de demanda de professores.

4. Encorajamos e recompensamos o saber e o saber fazer do ensino.

5. Criamos escolas organizadas para o sucesso dos alunos e dos professores.

Essas orientações serviram de ponto de apoio para diversas estratégias de ação, a maioria coerentes com um modelo profissional: elevação dos padrões de reconhecimento das escolas de formação de professores, sistema de certificação dos professores baseado em competências demonstradas, sobre um desempenho em situação real, após um ano nas "escolas de desenvolvimento profissional" (PDS), financiamento de programas de mentorado de professores em início de carreira, provisão de incentivos para atrair professores de qualidade onde eles faltam (notadamente nas escolas de meios desfavorecidos, urbanos ou rurais), desenvolvimento de um contínuo de carreira de maneira que os bons professores não deixem o ensino, estratégias para retirar das salas professores incompetentes, e programas alternativos de formação reservados a pessoas no meio da carreira e/ou desejosas de ensinar as matérias para as quais existe real penúria etc...

Assim se afrontam duas agendas de reforma da formação dos professores. Elas remetem a visões diferentes do ensino, de sua missão e da reforma da escola.

\section{O CONTEXTO DA CONCORRÊNCIA IDEOLÓGICA E A GÊNESE DO DEBATE ATUAL: UMA NAÇÃO EM RISCO (1983) E A NAÇÃO PREPARADA (1986)}

Podemos remontar a gênese do debate atual ao início dos anos 80 e ao famoso relatório da Comissão Nacional sobre a Excelência em Educação, intitulado Uma Nação em Risco. Consideramos esse relatório como encarnando o fim de uma época - a dos Trinta, gloriosa, da massificação e da democratização da escola e da cultura - e o início de uma outra, marcada pelo retorno em força de um discurso resolutamente economicista, centrado na eficácia e na produtividade da indústria do ensino, tornada necessária por uma concorrência mais viva entre as nações do mundo no contexto da globalização econômica. Esse discurso é o de uma certa direita americana, A Nação em Risco sendo publicado durante os anos da presidência de R. Reagan. É importante no que ele marca uma virada maior na política educativa, mas, como veremos mais adiante, a visão que se propõe não reina de maneira incontestada. 
Conhecemos a retórica ao mesmo tempo catastrófica e guerreira desse relatório. ${ }^{8}$ Lembramos que o relatório é fruto do trabalho de um grupo estabelecido em 1981 pelo Secretário de Educação, T. H. Bell, responsável pelo Departamento Americano (federal) de Educação, criado sob a presidência de Carter. ${ }^{9}$ Esse grupo compreendia presidentes de universidades (da Califórnia, da Louisiana e de Yale); universidades de alto nível, entre um prêmio Nobel de química, ${ }^{10}$ pessoal escolar (direção de escola, superintendente), responsáveis pela educação eleitos em nível dos Estados ou em nível local, bem como alguns representantes do mundo dos negócios. A Comissão não incluía nenhum representante de associações profissionais ou sindicais de professores, nem porta-vozes das faculdades de educação. Podendo se apoiar sobre uma percepção muito largamente espalhada no meio da opinião pública americana, ao menos na opinião do Secretário de Educação da época, no sentido de que a escola pública americana não estava à altura das expectativas da população, ${ }^{11}$ a Comissão tinha como mandato apreciar a qualidade do ensino e da aprendizagem nas escolas, nos colégios e nas universidades, e comparar as escolas e os colégios americanos com os de outras nações desenvolvidas. É principalmente da escola secundária - o high school- que a Comissão tratou.

$\mathrm{Na}$ continuação do seu trabalho, a Comissão analisou dados de pesquisa de diversas naturezas: primeiro, dados quantitativos sobre o resultado dos alunos de high school que serviram para sustentar a tese do declínio educativo dos anos 60 aos anos 80; análises curriculares tentando mostrar que os alunos escolhiam os cursos menos exigentes e que o real currículo do high school aparecia como um menu de lanchonete bastante variado, não muito rigoroso nem bem centrado num núcleo central de conhecimentos; análises das condiçôes de admissão dos colleges e das universidades, julgadas pouco exigentes e que se desejava ser revistas para cima; assim como os dados sobre o recrutamento, a formação, a carreira e a penúria de professores em certas matérias.

Uma Nação em Risco toma suas distâncias em relação aos discursos que dominaram a cena educativa americana ao longo do século 20: para a Comissão, o que mais está em jogo não é a contribuição da escola pública à integração dos imigrantes e à construção da nação americana, sua missão de desenvolvimento de uma cidadania democrática, o fosso entre um valor meritocrático e seu funcionamento real, notadamente no seu trato das minorias "visíveis", ou ainda sua capacidade de inovar segundo as ideologias pedagógicas dos anos sessenta. Em suma, o que está em jogo não remete às funções sociais e políticas da escola; trata mais do desempenho propriamente escolar da escola, esta sendo função das aprendizagens realizadas pelos alunos, mensuradas por testes estandardizados e percebidos como diretamente responsáveis pela competitividade da economia americana na cena mundial. Temos aqui em curso uma real redução do campo de interesse e de preocupação em torno da escola: é seu desempenho, definido em termos de resultados em testes estandardizados que está questionado, as dimensões mais abrangentes e mais tradicionais de sua missão estando relegadas ao estatuto de discursos antigos, certamente generosos, mas daqui para frente secundários, ou seja, cada vez menos pertinentes. 
A escolha dos dados de pesquisa retidos pela Comissão exprime essa redução do campo de interesse e essa concentração numa noção estreita de desempenho educativo. Sublinhamos que essa redução vai junto com uma dissociação da aquisição de saberes de seu contexto social e cultural: o desempenho da escola no plano dos saberes adquiridos pelos alunos está relacionado somente a características internas à escola. De fato, ele está associado a duas características principais do estabelecimento: de um lado, o currículo visto pelos cursos ofertados e o nível de exigências impostas aos alunos, e, de outro lado, os professores e suas qualificações disciplinares e pedagógicas. Com certeza, um terceiro elemento está incorporado na retórica de $A$ Nação em Risco, mas ele está na ordem das finalidades e não da explicação do "declínio" do desempenho educativo americano: é a importância dos saberes para o desenvolvimento econômico dos Estados Unidos.

Retrospectivamente, podemos sustentar que a comissão sobre a excelência em educação exprime bem a colocação na penumbra de um discurso "social" sobre a escola, preocupado com a igualdade e generoso para com as camadas sociais desfavorecidas ou discriminadas e que articula, amplifica e legitima um discurso mais economicista e gerencial sobre a escola. Esse discurso está centrado sobre a eficácia e a produtividade e toma forma na corrente de pesquisa dita da escola eficaz.

O relatório A Nação em Risco foi criticado pelo seu discurso alarmista sobre o estado das escolas e dos saberes dos alunos. Assim, a tese do declínio remete a uma pretensa era de ouro, largamente imaginária. A Comissão também foi alvo de numerosas críticas a respeito da pesquisa e de dados quantitativos utilizados e notadamente da grande confiança que lhes inspiravam os testes como o SAT, os do College Board, os da Avaliação Nacional do Progresso Educacional e os testes internacionais. Como reconhece hoje D. Ravitch (2003, p. 35), os dados quantitativos disponíveis a respeito da qualidade da educação americana são limitados e parciais e sabemos pouca coisa sobre as desigualdades de sucesso. Surpreendentemente, ao mesmo tempo em que adota o essencial das orientações do relatório, ela afirma que:

Enquanto o público americano aceita a validade de quase quaisquer resultados de testes, os especialistas em testes não aceitam. Portanto, os especialistas em testes não estão felizes com a maioria dos testes. Parece justo dizer que precisamos de testes que reflitam com acuidade o currículo que está sendo ensinado e que relatem os resultados em tempo hábil (2003, p. 35).

O que diz a comissão sobre os professores? Essencialmente, que eles são recrutados pela universidade a maioria das vezes entre o percentual mais fraco dos diplomados dos high schools e dos colleges. Que a formação dos professores nas faculdades de educação atribui importância demais às questôes de "métodos" e não suficientemente às matérias a ensinar. Que esta última situação é preocupante para o primário. Que há uma penúria em certas matérias, notadamente em matemática, ciências e línguas estrangeiras, e que essa penúria é em grande parte responsável pelo fato de em um grande número de classes 
- entre um terço e a metade, segundo dados colocados à disposição da Comissão - essas matérias não serem ensinadas por professores qualificados. Enfim, que a carreira dos professores não é suficientemente reconhecida, nem monetariamente, nem estatutariamente (a idéia de uma hierarquização das etapas da carreira).

Em suma, a mensagem da Comissão a respeito dos professores apresenta-se de maneira simples e direta; é necessário recrutar os melhores e suprir as necessidades, notadamente nas matérias com forte ênfase tecnológica e econômica, as ciências, as matemáticas. Neste propósito, a formação dos professores deve assegurar que os futuros professores sejam capazes de atender as exigências acadêmicas elevadas, que eles devem demonstrar uma aptidão para ensinar e dominar a disciplina que eles desejam ensinar. E as faculdades de educação deveriam ser julgadas em função da qualidade de seus diplomas. Assim, visto que o domínio dos saberes disciplinares é em definitivo mais importante que a pedagogia, a fim de preencher a penúria de professores, é preciso recrutar para o ensino mais amplamente que somente entre os diplomados das faculdades de educação. Tornase possível o acesso ao ensino, depois de uma formação pedagógica mínima (adquirida possivelmente na mesma escola do primeiro emprego, sob a orientação de professores experientes), a diplomados universitários de ciências ou de matemáticas, a engenheiros ou a cientistas em exercício ou aposentados, mas interessados no ensino. De outro lado, a comissão está de acordo que centros científicos importantes tenham a capacidade de formar ou de reciclar cientistas para o ensino.

Em nome da penúria real e construída, ${ }^{12}$ a porta está então aberta para uma revisão da política de formação dos professores e ao mandato confiado para esse fim às faculdades de educação. De acordo com Chester E. Finn (2003), a visão da comissão sobre a excelência em educação a respeito dos professores não é profissionalizante. Ele a qualifica mais como instrumental: os professores, conforme a Comissão, devem ser vistos como trabalhadores importantes de uma indústria com desempenho baixo que tenta se tornar mais produtiva e eficiente, o que supõe uma preocupação com a qualidade e a eficácia da mão de obra do ensino.

"Encontramos em Uma Nação em Risco nenhuma chamada de clarim para "dar poder" aos professores ou encarregá-los de decisões educacionais chaves ou reinventar as escolas ao seu redor. O bem-estar deles e o realço de sua profissão não foram as preocupações mais prementes da comissão. Em vez disso, os professores foram vistos como ingredientes chaves nas escolas, um insumo que precisava ser alterado - junto com o tempo, currículo, e padrōes - de modo a tornar as escolas mais efetivas" (2003, p. 213).

Avaliando o caminho percorrido por 20 anos, Finn estima que, após o relatório da Comissão sobre a excelência em educação, transformaçôes significativas da escola americana foram realizadas, notadamente nos planos de currículo e das exigências ("padrōes") para os alunos. No que concerne aos professores, segundo ele, poucas mudanças viram a luz do dia. Por quê? Duas razões principais são evocadas: a forte 
resistência do "estabelecimento" educativo (os sindicatos de professores, as instituições de formação de professores e burocracias educativas dos Estados) e a emergência sustentada, por esses mesmos grupos resistentes, de um discurso de natureza profissionalizante. Para Finn, esse discurso, materializado no relatório Uma Nação Preparada, produzido em 1986 pela Força Tarefa sobre o Ensino como Profissão da Fundação Carnegie, é contrário ao de $A$ Nação em Risco:

"O aspecto mais notável de Uma Nação Preparada foi uma sutil embora mais profunda mudança de foco: de professores como instrumentos da melhoria escolar a professores como artesãos da melhoria escolar. De professores como meios a professores como fins. De professores como pessoal num sistema educacional dirigido por outros, a professores como decisores a respeito do propósito e operaçôes do próprio sistema. Pode se dizer de professores como trabalhadores a professores como chefes" (2003, p. 218).

A leitura que Finn propõe do relatório Uma Nação Preparada é justa. De fato, se este relatório do grupo de trabalho sobre a educação e a economia da Fundação Carnegie parte das mesmas constatações que as do relatório Uma Nação em Risco, mesmo interpretadas diferentemente, ele não tira daí as mesmas conclusões. Para esses autores, se o sistema escolar americano é deficiente, não é tanto porque ele esteja em declínio ou medíocre; é mais porque ele esteja inadaptado ao contexto atual e principalmente incapaz de enfrentar os desafios da sociedade e da economia do saber. Não se trata de restaurar uma pretensa era de ouro, mas trata-se de resolutamente olhar para frente e agir em função dos interesses bem compreendidos da nação. Se os Estados Unidos querem continuar sendo uma potência econômica de primeiro plano, se eles desejam conservar o seu nível e sua qualidade de vida superior, num contexto de mundialização econômica onde os países em desenvolvimento recuperam cada vez mais empregos pouco especializados, é importante formar uma mão de obra cada vez mais qualificada, a fim de manter uma vantagem competitiva no plano dos setores de atividade e dos empregos de alto valor. Este discurso economicista torna imperioso o sucesso escolar para todos:

Se nosso nível de vida deve ser mantido, se o crescimento de uma subclasse permanente deve ser evitado, se a democracia deve funcionar efetivamente no próximo século, nossas escolas devem formar a grande maioria de seus estudantes...

É claro que, para conseguir isto, deve ser revista a elevação das exigências do currículo americano no nível secundário, mas este não pode gerar os frutos esperados a não ser que os professores sejam profissionais de qualidade:

“...a chave do sucesso está em criar a profissão igual à tarefa - a profissão de professores bem educados, preparados para assumir novos poderes e responsabilidades para redesenhar as escolas do futuro. Sem a profissão repleta de habilidades elevadas, capacidades e aspirações, qualquer reforma durará pouco. Construir tal profissão - para restaurar o diferencial da nação - a força tarefa faz apelo a mudanças majestosas na política educacional” (1986, p. 2). 
As mudanças desejadas pelo manifesto Uma Nação Preparada constituem dimensões da profissionalização do ensino e da formação dos professores. Trata-se de criar uma espécie de ordem profissional nacional, encarregada de definir e de supervisionar o respeito aos "padrões" nacionais de competência profissional (um Conselho Nacional por Padrōes Estandardizados de Ensino), reestruturar as escolas e rever a organização do trabalho dos professores de maneira que estes sejam coletivamente autônomos em nível dos meios e dos dispositivos pedagógicos privilegiados e responsáveis pelos resultados dos alunos, introduzir progressivamente um plano de carreira hierarquizado, e implantar uma formação de professores incluindo uma graduação disciplinar e um mestrado em ensino, bem como melhorar as condiçōes estatutárias (salários, recompensas, etc.). Notamos que essas medidas em ensino serão essencialmente retomadas de 1986 a 1996 por diversos relatórios do Grupo Holmes ${ }^{13}$ e que algumas serão parcialmente colocadas em aplicação (LESSARD, 2003).

Os dois relatórios são de alguma forma contemporâneos: se o primeiro data de 1983, o segundo é de 1986. Emergem assim dois discursos e duas agendas ${ }^{14}$ diferentes e em boa parte contraditórios sobre o lugar e o poder dos professores na escola e nas decisões relativas ao ensino dispensado. Mas teria mais em pauta. $\mathrm{Na}$ verdade, duas visóes de ensino e da aprendizagem se afrontaram: uma visão mais tradicional, centrada na transmissão dos conhecimentos e bem vista pelos pais, e uma outra visão, mais moderna, socioconstrutivista, centrada na aprendizagem e no professor como facilitador, treinador e mentor. Esta segunda visão seria adotada pelo estabelecimento educativo. A primeira chama um redirecionamento da situação, a implantação de medidas administrativas e pedagógicas mais eficazes; a segunda comanda uma "reestruturação", ou seja, uma "reculturação" da escola.

"A diferença chave é que a equipe da Carnegie procurou deslocar mais poder (e recursos) para as mãos de educadores e de seus grupos de interesse, enquanto a Comissão sobre Excelência parecia contente com providências de 'controle de civis' que tradicionalmente caracterizam a governança do sistema" (FINN, 2003, p. 221).

Poderíamos com toda razão pensar que Finn, cujas pertenças e orientações ideológicas neo-liberais são conhecidas e claramente afiadas, radicaliza as diferenças entre as duas correntes e os dois grupos, porque ele busca mostrar que os grupos que sustentam a profissionalização do ensino desviaram o vento da reforma que soprava nos Estados Unidos no início dos anos 80 em favor de uma maior eficácia e desempenho das escolas, em direção a um maior reconhecimento estatutário dos professores e um poder maior do estabelecimento educativo sobre a escola e sobre a organização da formação dos professores. Finn não está errado em considerar a ideologia da profissionalização como concorrente daquela sobre a eficácia e sobre o desempenho. De fato, a primeira adota uma concepção mais ampla do sucesso do aluno e da eficiência do estabelecimento e ela estima que a missão do professor ultrapassa sua capacidade de poder aumentar os resultados de um grupo de alunos em testes estandardizados. 
Finn culpa também os profissionalistas de quererem se subtrair ao controle externo e de serem insensíveis às demandas dos pais. Para ele, o socioconstrutivismo, que é um ingrediente da ideologia das ciências da educação, afasta o ensino dos pais:

"A visão de capacidades e conhecimento da aprendizagem do aluno é mais avantajada tratando os professores como técnicos especialistas que são talentosos em implementar os desenhos dos outros. Eles também devem ter de prestar contas a outros fora da profissão por resultados educacionais que são em grande parte formatados fora do sacerdócio de especialistas. Colocando isto de modo simples: o apelo do público por capacidades básicas e conhecimento colide com a pressão dos educadores por um maior profissionalismo" (2003, p. 228).

Ele esquece que as duas correntes e os dois grupos compartilham as mesmas idéias a respeito da revisão necessária à elevação das exigências de formação dos professores, de um melhor recrutamento, assim como de melhores condiçôes de desenvolvimento profissional e de supervisão ao longo de toda a carreira. De certa maneira, em cavando a vala entre as duas visões, Finn, em nome dos desregulamentacionistas, sustenta que a agenda da profissionalização tem, de fato, freado a preocupação com um desempenho maior dos professores, e está ligada à aprendizagem mensurada dos alunos.

"A procura pelo profissionalismo de professores tem jogado um trunfo ao impulso por melhor desempenho de professores. Tem se tornado um objetivo de política no seu direito próprio, o qual obscurece a visão de professores como instrumentos para produzir mais aprendizagem em crianças e um desempenho melhor pelas suas escolas. E tem se tornado um objetivo sobre o qual muita atividade de política tem se centrado" (2003, p. 224).

Para os desregulamentacionistas, o que está em jogo é a contribuição das duas agendas de reforma à melhoria das aprendizagens dos alunos. Daí a questão que eles colocam: que dados de pesquisa sustentam uma ou outra agenda? Temos realmente provado que um professor diplomado de uma faculdade de educação tem um efeito mais positivo sobre as aprendizagens dos alunos que um professor sem formação pedagógica (mas com pelo menos uma formação disciplinar universitária)? Como ele se organiza para demonstrar isto?

Por outro lado, para os profissionalistas, uma questão prévia deve ser colocada: de que aprendizagem estamos falando? Com efeito, os profissionalistas estimam que a escola do futuro, aquela que poderá inserir seus diplomados na sociedade do saber, deverá desenvolver nesses alunos competências e conhecimentos de alto nível, que não são facilmente mensuráveis, em todo caso, por testes estandandardizados centrados nas aquisições e não em capacidades. Os profissionalistas têm então uma concepção mais ampla e aberta da aprendizagem, enquanto que os desregulamentacionistas trazem-na de volta ao que pode ser quantitativamente mensurado em escala de um sistema. 


\section{O DEBATE CIENTÍFICO: QUE PESQUISA DE QUALIDADE PARA QUE PROPOSIÇÃO DE POLÍTICA?}

Apesar do reconhecimento nos dois grandes pólos do espectro ideológico, das divergências de orientaçōes e de valores, em certo modo além das divergências e da polarização das posiçôes adotadas, o acordo entre as partes no debate existe sobre alguns pontos maiores, que estruturam consideravelmente a discussão científica. O primeiro ponto de acordo trata da importância da "política baseada na evidência", isto é, sobre a ideia de que a política educativa deve se apoiar ao máximo, ou seja, decorrer diretamente da "pesquisa” de qualidade, e não da "ideologia”. O segundo trata da ligação necessária entre as características dos professores (ou seja, a formação) e a aprendizagem dos alunos: um bom professor faz com que seus alunos aprendam, e isto é mensurável. Com estes dois elementos, assim como tentaremos mostrar nos parágrafos a seguir, o debate nos seus aspectos científicos torna-se ao mesmo tempo especializado e bastante polarizado, mascarando assim uma importante zona de acordo.

Podemos apresentar sob a forma de quatro proposições os elementos essenciais do debate científico.

Primeira proposição: a pesquisa mostra que os professores "fazem uma diferença'. Uma vez controlados os efeitos do meio ambiente e das características dos alunos, o professor, mais que qualquer outra característica da escola, tem um efeito significativo sobre a aprendizagem dos alunos, e esse efeito é durável. Os dois lados do debate reconhecem o fundamento desta proposição e estimam que um bom número de pesquisas empíricas de qualidade apresenta uma prova convincente.

Segunda proposição: a pesquisa fornece elementos de resposta à seguinte questão: quais são as características do professor que fazem uma diferença? Esses elementos são incompletos, uma vez que nem tudo é mensurável (LACZKO-KERR; BERLINER, 2002) e o ensino de qualidade permanece misterioso (GOLDHABER, 2002); por outro lado, eles são úteis para orientar as políticas. Os dois partidos no debate reconhecem a importância demonstrada de uma formação disciplinar (mensurada por um diploma de graduação ou uma licenciatura), da experiência até certo nível, além do qual ela nada vale ou muito pouco) e da habilidade verbal. No que concerne à formação disciplinar, numerosos estudos sobre o ensino fora do campo disciplinar no secundário mostram que, sem dúvida nenhuma, a aprendizagem dos alunos, notadamente nas matérias científicas, é mais segura se ministrada por professores com uma formação disciplinar pertinente. Quanto ao efeito da habilidade verbal, ele foi medido pela primeira vez na famosa pesquisa de Coleman (1966) no decorrer dos anos sessenta, e muitos Estados americanos integraram depois nos seus testes de certificação de professores uma medida de habilidade verbal (bem como, de outra parte, exames da competência disciplinar).

O que não configura consenso é o status dado a estas variáveis. Para os adeptos da desregulamentação, a habilidade verbal é considerada como o melhor e único fator de 
predição digno de nome de eficiência do professor. Como sublinha Darling-Hammond (2002), um bom número de estudos que mensuraram a habilidade verbal e a formação disciplinar não incluíram no seu desenho de pesquisa as variáveis ligadas à formação pedagógica, a certificação ou diversos aspectos pertinentes à formação dos professores (como os estágios). Esses estudos podem então corroborar os efeitos incontestados das variáveis mensuradas, mas eles não podem ser utilizados para sustentar que as variáveis relacionadas à formação pedagógica e à certificação não têm nenhum efeito, já que não foram mensuradas.

É a mesma coisa com relação ao status dado à formação disciplinar. Assim como afirma Darling-Hammond (2002), seria ridículo considerar que a competência disciplinar é sem importância, mas, segundo ela, é igualmente ridículo sustentar que o conhecimento do ensino e da aprendizagem, assim como a possibilidade estruturada de ensinar sob a supervisão de um professor experiente no quadro de uma formação prática bem enquadrada, seja sem consequência. Portanto, os desregulamentacionistas, estimando que a pesquisa "séria" sustenta verdadeiramente a importância da formação disciplinar, são de opinião que os políticos deveriam tornar obrigatório somente esta formação e não a outra de natureza pedagógica, assim relegada ao status de opcional ou facultativa. Os desregulamentacionistas exibem aqui um ponto de vista bastante simplista da relação entre a pesquisa e a elaboração das políticas: estas não devem ir além do que a pesquisa demonstra. O que não é comprovado empiricamente, ou de maneira incerta e ambígua, não deve ser objeto de legislação. Deve ser dito que os desregulamentacionistas buscam desfazer um arranjo institucional que eles apresentam sempre como o monopólio das faculdades de educação sobre a formação. É então bom manter a guerra tentando mostrar que a pesquisa "séria" não justifica a manutenção desse monopólio.

Notamos que é empiricamente difícil separar os efeitos dos dois tipos de formação, disciplinar e pedagógica, porque, se é verdade que existem nas escolas americanas professores com formação disciplinar e sem formação pedagógica, o inverso é quase impossível. De fato, um diplomado de uma instituição americana de formação de professores recebeu uma formação ao mesmo tempo disciplinar e pedagógica. De tal forma que, quando se mensura o efeito de um diploma de educação sobre a eficiência dos professores, esse diploma revela a influência potencial das duas formações inextricavelmente ligadas. Para os desregulamentacionistas, o fato de que não se isolou o efeito da formação pedagógica constitui uma falha importante da prova apresentada pelos profissionalistas.

Estes últimos retorquem adiantando uma concepção mais ampla da especialização em ensino. Poderíamos dizer que eles adiantam uma visão multidimensional e menos reducionista da qualidade do ensino. Certamente, eles retêm e integram as variáveis que os desregulamentacionistas estimam ser cientificamente incontornáveis, mas eles as colocam dentro de um conjunto mais complexo e rico. Conforme Darling-Hammond (2002): 
[...] pesquisa sobre ensino sugere uma visão de especialista que inclui conhecimento geral e habilidade, habilidade verbal e conhecimento da matéria como fundações; habilidades para planejar, organizar, e implementar tarefas complexas como fatores adicionais; conhecimento de ensino, aprendizagem e crianças como base para agregar e aplicar conhecimento em situações não rotineiras.

Existe então um debate sobre a importância de uma formação pedagógica prévia ao exercício da profissão, e, por implicação, sobre a necessidade de fazer desta uma exigência de certificação dos professores. Como a pesquisa pode contribuir para fatiar esta questão? No contexto americano, uma sub-questão de pesquisa está rapidamente associada à primeira: se é necessário formar futuros professores em algo diferente que os conteúdos de ensino, os programas universitários de bacharel em educação são mais performantes que programas "alternativos", mais curtos, dispensados algumas semanas antes de assumir a função e muitas vezes geridos pelas autoridades locais?

Terceira proposição: para que a pesquisa empírica seja em condições de contribuir para esclarecer estas questóes, ela deve ser de qualidade. O que é uma pesquisa de qualidade? Por conta da Fundação Abell, K. Walsh (2001) produziu uma analise secundária da pesquisa sustentando a importância da formação pedagógica e da certificação dos professores. Essa análise tratou de 175 estudos empíricos realizados ao longo dos últimos 50 anos e mencionados pelos profissionalistas nos seus argumentos a favor da formação pedagógica obrigatória. Entre esses estudos, Walsh criticou severamente a pesquisa efetuada por Darling-Hammond (2000). Essa análise de Walsh é muitas vezes citada ${ }^{15}$ e DarlingHammond sentiu a necessidade de replicar num texto de umas 50 páginas (2002). Podemos então considerar esses dois documentos como expressando e discutindo concepções de qualidade da pesquisa em educação. Nesta qualidade, é importante dedicar-se um pouco a ela.

Walsh faz um julgamento severo sobre o conjunto da pesquisa analisada; ele parece "deficiente, pouco rigoroso, envelhecido e às vezes desonesto" (2001, p. 13). Esse julgamento se traduz em oito críticas formuladas de maneira polêmica e categórica. Sublinhamos que Walsh elimina um grande número de pesquisas por uma ou outra das razóes a seguir: umas 20 teriam envelhecido (elas teriam sido publicadas antes de 1980); ${ }^{16}$ outras se apoiam em pequenas amostras de professores; outras não utilizam como medida da variável dependente os resultados dos alunos, mas substitutos da eficiência do professor que ela rejeita, porque, aos seus olhos, subjetivos demais, como a avaliação do desempenho do professor por um supervisor, de medidas apoiadas em observação em classe pelo pesquisador, o sentimento de eficácia do professor; enfim, algumas são teses não publicadas, relatórios técnicos de pesquisa, comunicações em colóquio e não artigos científicos publicados em revistas cujo sistema de avaliação pelos pares está solidamente estabelecido. Como sublinha Darling-Hammond (2002), se é legítimo apontar vários problemas metodológicos associados ao tamanho das amostras, às medidas utilizadas, ao envelhecimento da pesquisa nas ciências sociais aplicadas, é, por outro lado, discutível 
eliminar sistematicamente todo resultado de pesquisa sob pretexto de que um ou outro critério de qualidade não seja completamente respeitado.

Seguindo Walsh, a pesquisa de qualidade produz então dados "duros", incontestáveis. Neste caso, isso passa por amostragens de professores, de grande tamanho, permitindo análises estatísticas concludentes e generalizáveis, medidas das variáveis objetivas, independentes das percepções dos atores (isto é, os resultados dos alunos a testes estandardizados), e um relatório da pesquisa avaliado pelos pares e publicado em artigo numa revista de bom nível científico.

Walsh discute também a pesquisa efetuada por Darling-Hammond (2000). Mesmo que esta satisfaça os critérios precedentes de qualidade, ela apresenta, aos seus olhos, uma dificuldade importante, ligada ao nível de agregação dos dados analisados. De fato, Darling-Hammond estudou as diferenças entre os Estados americanos em matéria de políticas educativas (relativas à formação e à certificação dos professores) e foi capaz de sustentar, por análises de correlação e de regressão, que os Estados que têm um nível elevado de professores certificados veem seus alunos ter mais sucesso nos exames de matemática nas $4^{\mathrm{a}}$ e nas $8^{\mathrm{a}}$ séries, bem como nos exames de leitura na $4^{\mathrm{a}}$ série. Aqui, a certificação completa significa que os professores possuam uma formação no tocante à formação disciplinar e pedagógica. Ademais, esses dados agregados ao nível do Estado indicariam que o sucesso dos alunos está mais fortemente ligado à qualidade dos professores (proporção de professores certificados) que ao tamanho da classe, ao nível de despesas consagradas à educação ou aos salários dos professores.

Walsh critica não os resultados dessa pesquisa, mas a leitura que se pode fazer dela e à qual lhe parece que Darling-Hammond não consegue se premunir. Com efeito, ela menciona que não se pode passar de um nível de análise para outro de maneira automática: assim, não é porque os Estados que têm uma proporção mais alta de professores certificados têm também alunos que têm mais sucesso, que pode se concluir que a relação entre certificação e sucesso escolar é também comprovada para cada distrito escolar e para todas as classes. Múltiplas variáveis podem vir modificar a relação documentada a um nível de análise. Por exemplo, a rede escolar no interior dos Estados não é forçosamente homogênea; grandes variações entre os distritos escolares, nos planos financeiros, de meios socioeconômicos e de tamanho das classes, podem embaralhar uma relação aparentemente forte em nível de estado tomado no seu conjunto. Da mesma forma, os alunos não são homogêneos e reagem diferentemente aos diferentes tipos de professores. Walsh conclui que temos aí um erro estatístico sério, porque deforma os resultados e leva o leitor a considerá-los como válidos para um nível de análise ao qual eles não se referem.

Darling-Hammond (2002) replica o conjunto dessas críticas. Da mesma maneira que ela sustentava acima uma concepção da qualidade da pesquisa menos restritiva e mais aberta à diversidade das metodologias de pesquisa e dos níveis de análise. Com 
efeito, segundo ela, métodos diferentes de pesquisa ou mistos atendem a funções complementares. Assim, pequenos estudos experimentais ou quase-experimentais permitem melhor descrever e compreender um fenômeno e as relações entre as variáveis importantes. Estudos realizados em níveis diferentes de análise podem também permitir construir uma visão mais sistemática do fenômeno em estudo. Em suma, se a qualidade de uma pesquisa deve ser mensurada em função de critérios precisos, se ela deve ter um valor científico em si mesma, é importante situar mais amplamente sua contribuição à construção de um corpo de conhecimento sobre um dado objeto, consistente e coerente. Assim, colocada dentro de um conjunto mais amplo, a consistência, até mesmo a preponderância, dos resultados de diversas pesquisas, obedecendo a diversas metodologias e construídas em diferentes níveis de análise, parece de grande importância. E nesse ponto Darling-Hammond sustenta que o corpo de pesquisas existentes que ela analisou (2000 e 2002) demonstra a importância da certificação dos professores.

Em suma, duas concepçôes da qualidade da pesquisa em educação se opõem aqui, uma que se apresenta como restritiva e rigorosa, eliminando uma boa parte da produção científica porque os dados que utiliza parecem "moles", subjetivos, em número insuficiente para generalizar qualquer coisa, e, a outra, recusando-se a aplicar de maneira "automática" os critérios retidos pela primeira concepção e insistindo sobre as virtudes científicas da diversidade dos métodos e dos níveis de análise.

Esse debate interessante é bem conduzido pelos adeptos das duas posiçôes. Por outro lado, não vendo saída possível, podemos pensar que ele está sendo chamado a se renovar sem parar.

Quarta proposição: formulada de maneira interrogativa: se se tornar importante aprender esta profissão, como aprendê-la de maneira eficiente? A questão de política educativa é mais direta e menos geral: os programas alternativos de certificação são tão ou mais eficazes que os programas universitários longos?

Para os desregulamentacionistas, os programas alternativos apresentam vantagens empiricamente verificadas. Com efeito, eles permitem responder rapidamente a uma situação de penúria, em certas matérias, no meio rural e em meio urbano pobre. Também eles atraem pessoas diferentes da clientela típica de uma faculdade de educação: são geralmente adultos que não passaram toda sua vida no quadro de uma instituição escolar e que têm uma experiência profissional rica e eventualmente estimulante para os alunos. De outra parte, C. E. Finn chama-os de pessoas "em trânsito de carreira" e ele considera sua contribuição como positiva para a educação dos jovens, mesmo que o julgamento dependa mais do senso comum que da pesquisa científica. Os desregulamentacionistas esquecem de mencionar que esse tipo de professores tem tendência a deixar o ensino mais rapidamente que os professores certificados, provavelmente porque eles são levados a trabalhar em contextos difíceis, onde uma formação mais importante se revela necessária, conforme os profissionalistas. 
Por outro lado, os desregulamentacionistas citam estatísticas no sentido de que as faculdades de educação recrutam seus estudantes entre os diplomados mais fracos do secundário. O Secretário de Educação do governo federal, M. R. Paige, cita esses dados no seu relatório sobre a qualidade do ensino (2002) e utiliza-os para sustentar os programas alternativos. Darling-Hammond replica com cifras recentes mostrando a progressão dos escores dos estudantes em formação de professores no famoso SAT (Teste de Aptidão Escolástico).

Do seu lado, os profissionalistas insistem que, entre o conjunto dos programas alternativos de certificação, distinções devem ser feitas. De fato, a seus olhos, é importante distinguir os programas universitários de "pós-graduação" ou mestrado, que atraem estudantes detentores de um bacharelado disciplinar, de programas curtos ofertados pelo meio escolar, recrutando muitas vezes adultos desejando mudar de profissão, provenientes das minorias visíveis e dispostas a trabalhar em escolas de áreas pobres. No primeiro caso, permite-se a estudantes que não escolheram o ensino na hora da entrada na universidade se orientar em direção ao ensino, enquanto eles chegam a completar uma formação pedagógica e didática, bem como conseguir estágios em meio escolar. Que essas formaçōes sejam empiricamente demonstradas como eficazes alegra e conforta os profissionalistas na sua posição básica. No segundo caso, trata-se de programas de urgência, com vistas a assegurar o recrutamento de professores "qualificados" nas matérias nas quais existe uma penúria - real ou construída - e em distritos e escolas de áreas pobres e com forte densidade étnica (afro e latina). Essas formações não preveem a aprendizagem prática da profissão antes de tomar posse numa escola e elas não passam da cobertura dos programas a serem ensinados e das informaçôes necessárias à inserção profissional.

Entre esse segundo tipo de programa, o programa Ensinar para a América, graças ao apoio do governo federal, goza de uma aura particular. Portanto, conforme Laczko-Kerr e Berliner (2002), quatro avaliaçôes distintas mostram que o programa prepara mal os professores ao ensino. Um único estudo seria positivo, mas o acesso aos dados foi recusado aos pesquisadores (LACZKO-KERR; BERLINER, 2002) para uma análise independente. Esse estudo comparava a eficácia dos professores do programa Ensinar para a América à dos professores sem certificação. Isto tem levado Laczko-Kerr e Berliner a completar uma pesquisa comparando o efeito sobre o sucesso dos alunos dos professores certificados e dos professores não certificados. Utilizando um esquema quase-experimental, os pesquisadores fizeram pares de professores certificados e não certificados; os resultados mostram que os professores certificados têm alunos com resultados mais elevados no SAT 9 (em leitura e matemática), e isso para os dois anos em estudo, ou seja 1999 e 2000, para os quais dados foram coletados. Ademais, os professores formados no programa Ensinar para a América não se revelaram com desempenho melhor que os outros professores não certificados. 
Darling-Hammond ampliou o debate sobre os programas alternativos sublinhando a sua contribuição à manutenção das desigualdades sociais e escolares. Com efeito, segundo ela, tudo se passa como se as escolas públicas e privadas, ricas, situadas nas periferias, recrutassem professores certificados, diplomados de um programa universitário longo, enquanto as escolas públicas dos centros desfavorecidos e etnicamente densos das cidades devessem se contentar com professores não certificados ou formados nos programas alternativos de urgência. Em suma, duas classes de professores, a custos de formação diferentes, para um sistema escolar cada vez mais dualizado. Conforme DarlingHammond, em nome da equidade social, é importante combater essa opinião política. Para os desregulamentacionistas, somente a eficácia das formaçôes deve ser considerada.

Mesmo se os protagonistas do debate compartilham orientaçôes fundamentais - a pesquisa deve e pode fornecer a "evidência" necessária à elaboração das políticas de formação dos professores e em última instância, a eficiência de um professor pode ser mensurada pelos ganhos de aprendizagem dos alunos sob sua responsabilidade -, concepções diferentes da especialização em ensino e também da pesquisa educativa de qualidade os opõem e os levam a se engajar numa luta que aparece para os grupos interessados, suficientemente importante para mobilizar de um lado como do outro, representantes críveis, de grandes figuras (Darling-Hammond, Berliner, Floden, Ravitch, Finn etc.). Essa mobilização contribui com certeza para a qualidade do debate, mas também para sua polarização.

\section{CONCLUSÃO: SAIR DA POLARIZAÇÃO PARA MAIS CONCORRÊNCIA, MAS REGULADA PELA AVALIAÇÃO CIENTÍFICA, OU REINTRODUZIR A DIMENSÃO SOCIAL NA POLÍTICA EDUCATIVA?}

É claro que a administração americana atual sustenta a posição dos desregulamentacionistas. Num contexto político como esse, as faculdades de educação são colocadas na defensiva. Tendo aceito a politica baseada na evidência e a necessária ligação entre a formação e o sucesso escolar dos alunos, elas aparecem vulneráveis e dificilmente podem sustentar a sua posição monopolística. Por outro lado, seu discurso quanto ao fundo da questão em debate não entra em contradição direta com aquele dos desregulamentacionistas; mais exatamente, ele busca ampliar e complexificá-lo, notadamente no que concerne à concepção da aprendizagem dos alunos, da especialização em ensino, e da qualidade da pesquisa. De certa forma, essa estratégia reconhece, pelo menos em parte, o bem fundado da posição do outro. E, uma vez que se aceita estar no terreno do outro, é difícil sair indene quando em luta.

Seguindo essa linha de análise, a sugestão de Finn (2003) para sair da polarização atual é temível e de uma finura estratégica difícil de opor com sucesso por quem quiser "salvar" o monopólio das faculdades de educação em matéria de formação dos professores. Quem quiser que julgue. Finn propõe às partes: 
1. concordar sobre uma medida comum da eficácia dos diferentes dispositivos de formação, a saber, o valor adicionado da formação à aprendizagem mensurada dos alunos;

2. como, em teoria, muitos dispositivos e diferentes estratégias podem contribuir à aprendizagem dos alunos, ter abertura de espírito e disposição para a experimentação e não ser doutrinário ou dogmático;

3. respeitar a escolha dos Estados: os que vierem a optar pela agenda da profissionalização ou da desregulamentação deverão aceitar que seus efeitos sejam avaliados a longo prazo, graças a avaliações de qualidade e objetivas;

4. diversificar a formação dos professores e avaliar seus efeitos.

Essa proposição é sedutora, já que ela se apresenta como razoável, pragmática e conforme ao ethos político e cultural americano. Ela também é uma via de saída para os aspectos científicos do debate, uma vez que ela afirma que este debate avançará na medida em que o quase-mercado da formação se diversifica verdadeiramente, ao mesmo tempo em que se submete a uma avaliação científica contínua e rigorosa. Em se diversificando, esse quase-mercado da formação fornecerá aos pesquisadores condições que se aproximem de uma experimentação de diferentes dispositivos e poderão tirar da avaliação desses dispositivos conclusōes mais sólidas que as que podem formular a partir das condições atuais.

É também o que sustenta uma coalizão de especialistas num documento submetido ao Departamento de Educação americano. Essa Coalizão para uma Política Baseada na Evidência (2002) pressiona constantemente o governo federal americano para não sustentar financeiramente os esforços de pesquisa utilizando o método de experimentação controlada e aleatória numa grande escala (tentativas aleatórias) no objetivo de construir uma base de conhecimentos científicos. Essa base de conhecimentos não poderá tornarse prescritiva a não ser que ela esteja sustentada por esse tipo de pesquisa. Fora desse tipo de pesquisa, tudo é considerado como efeitos de moda ou de ideologia. Para a coalizão, esse tipo de pesquisa permitiu à medicina e à farmacologia se dotar ao longo dos últimos anos de uma base científica. Subestimando a problemática da generalização das inovações ou das experiências-piloto em educação, a coalizão estima que a profissionalização do ensino passa pela implantação de um equivalente educativo na instância americana da aprovação dos medicamentos.

De sua parte, o decano da faculdade de educação da Universidade Northwestern de Boston, J. Fraser (2002), aceita essa idéia de um quase-mercado da formação submetido a uma avaliação do valor adicionado dos diplomas e tenta convencer seus colegas a fazer o mesmo. Ele estima que se colocar numa posição defensiva para as faculdades de educação é mais perigoso do que assumir os riscos do desaparecimento do atual monopólio e da viva concorrência que poderia vir a seguir entre os diversos modos de formação dos professores. Segundo ele, o fim do monopólio terá como consequência dar mais liberdade 
às universidades, já que delas não será exigido se submeter às políticas e às legislações dos Estados em matéria de formação dos professores. Elas poderão assim construir o currículo de formação que elas estimam fundado sobre o estado dos conhecimentos ("estado da arte"). Conforme Fraser, nesse contexto desregulamentado, a pesquisa sobre a eficácia da formação dos professores se desenvolverá, em grande parte, segundo as pistas balizadas pela Comissão Nacional sobre Ensino e o Futuro da América.

Pode existir uma alternativa? É difícil de responder. Em todo caso, não se vê que ela venha a emergir e a se construir nos Estados Unidos atuais. A nosso ver, a única alternativa possível passa por uma reintrodução no debate de um forte componente de uma ideologia com conotação social e de uma crítica ao mesmo tempo das instituições atuais de formação e das teses dos desregulamentacionistas para sua contribuição às desigualdades sociais e à hierarquização das escolas. O risco, entretanto, é de parecer querer opor a ciência ou a pesquisa e a ideologia. Possivelmente não, porque nada impede aos profissionalistas trabalharem na construção de bases de dados de natureza a sustentar sua tese. Afinal de contas, Bourdieu e os outros teóricos da reprodução elaboraram sua teoria se apoiando em análises empíricas rigorosas.

O debate americano sobre a formação e a certificação dos professores nos obriga a refletir sobre as relações entre a ciência e a ideologia. Certamente, os partidos levam muito a sério esse debate que dura já há duas décadas. Investiram nele uma importante capacidade de mobilização e de trabalho em rede de numerosos estudos empíricos e meta-análises das pesquisas existentes. Eles até contribuíram em refinar certas metodologias apropriadas ao estudo do efeito-professor e construíram argumentos fechados nomeando os pontos fundamentais de acordo e de desacordo entre os partidos. Existe aí um verdadeiro debate. ${ }^{17}$

Paradoxalmente, o debate mostra que quanto mais se procura evacuar a ideologia do debate, considerando toda referência ideológica ilegítima numa vontade de submeter a elaboração das políticas educativas somente a resultados científicos "incontestáveis", mais de alguma forma a ciência é ligada a uma ideologia particular que recusa ser nomeada como tal. Os desregulamentacionistas, dedicados à ciência da medida empírica rigorosa, adotam uma concepção da aprendizagem que não é neutra e eles têm uma visão da especialização em ensino e da formação exigida para desenvolvê-la que participa do modelo secular do artesão instruído (PAQUAY, 1994). Nestas matérias, não pode haver referência a valores, a concepções do desejável.

A concepção dos desregulamentacionistas a respeito da relação entre a ciência e a política é estranhamente silenciosa sobre as inevitáveis e necessárias mediações ideológicas entre, de um lado, a ciência e os julgamentos de fato, e, de outro lado, a política e os julgamentos de valor. De fato, essa concepção deve ser qualificada como estreita e reducionista, já que, em suma, a tese fundamental consiste em sustentar que o Estado não deve elaborar políticas limitantes para os atores e impor práticas a não ser que a 
ciência incontestavelmente sustente nos fatos suas pretensões. Caso contrário, ele deve se abster e deixar fazer. Isto é evidentemente um pouco curto e ao mesmo tempo de uma pretensão hegemônica: somente a ciência pode fatiar questões litigiosas, transcender os interesses particulares e encarnar o bem comum. É devido ao fato de a ciência ser imperfeita ou insuficientemente desenvolvida que a política é submetida a efeitos de moda, de interesses "corporativistas" ou tendências ideológicas. Para se opor com sucesso a essas modas e esses desvios, é necessário então desenvolver a ciência, aquela que produz julgamentos de fatos "incontestáveis". Deste modo, a política com base em evidência se desenvolverá e reunirá todos os atores ao redor de um bem comum cientificamente definido.

Longe de nós a idéia de que a pesquisa avaliativa seja inútil ou que a política baseada na evidência seja banida. É bem mais a armadilha que elas compreendem que deve ser submetida à crítica. Essa armadilha consiste em reduzir a aprendizagem ao que pode ser mensurado, a especialização em ensino à sua eficácia, concebida como valor agregado e o valor da educação à sua instrumentalidade. Para evitar essa armadilha, devemos lembrar a posição weberiana de irredutibilidade dos tipos de julgamentos.

\section{Notas}

1. Mesmo que a maior parte dos professores das escolas privadas americanas sejam de fato certificados, as escolas privadas não são obrigadas a contratar professores certificados. Somente as escolas públicas devem se submeter a esta exigência.

2. Linda Darling-Hammond é professora de educação na Faculdade de Educação da Universidade de Stanford na Califórnia. Ela é diretora geral da Comissão Nacional sobre Ensino e o Futuro da America (CNEFA).

3. Diane Ravitch é atualmente " professora pesquisadora» na Universidade de Nova Iorque; é também "pesquisadora não residente sênior" na Instituição Brookings em Washington. Portadora de um doutorado em história na Universidade de Colômbia (Nova Iorque), no início de carreira ela foi professora de história da educação na Escola Normal dessa renomada universidade. Nos anos 80, ela foi associada ao trabalho do grupo de especialistas na origem do famoso relatório Uma Nação em Risco. Ao longo dos anos 90, ela foi secretária adjunta de Educação e foi responsável pela direção de pesquisa e desenvolvimento em educação do Departamento Americano (federal) de Educação. Ela é membro da Fundação Fordham, que defende a agenda da desregulamentação da educação em geral, e na área de formação de professores em particular.

4. Essas políticas em geral afirmam que a educação não é uma questão de partidos, que ela deve transcender as linhas partidárias, em nome do interesse público. Podemos pensar que sua participação na atividade de uma fundação é interessada: eles encontram ali um reservatório de idéias e análises que podem alimentar sua própria agenda política.

5. Formado em Harvard, onde detém um doutorado em política educacional, C. E. Finn foi professor de educação e de política pública na Universidade de Vanderbilt durante 20 anos. Como a Sra. Ravitch, mas antes dela, de 1985 a 1988 ele foi secretário adjunto de Educação e foi responsável pela direção de pesquisa e desenvolvimento em educação do departamento americano (federal) de Educação. Ele assinou o relatório Uma Nação em Risco (1983). Ao longo 
dos anos, ele trabalhou para várias fundações e preside atualmente a Fundação Thomas B. Fordham e o Instituto Thomas B. Fordham. Ele também é "pesquisador sênior" da Instituição Hoover da Universidade de Stanford: ele é "pesquisador adjunto" do Instituto Hudson. Antes disto, ele foi pesquisador associado da Instituição Brookings e "pesquisador John M. Olin" no Instituto Manhattan. Muito ativo, o Sr. Finn escreveu mais de 350 artigos e 14 livros, segundo as informações do site da internet da Fundação Fordham. Por fim, sublinhamos sua participação no Projeto Edison, projeto de tomada de poder pela empresa privada de distritos escolares e de escolas públicas neles incluídas e de instalação de uma administração que obedeça aos princípios da nova gestão pública. O Sr. Finn foi parceiro fundador desse projeto, bem como pesquisador sênior. Ele é um ardente defensor da desregulamentação em educação.

6. Cada Estado fica livre para legislar como bem entende nesta matéria e de acrescentar outros elementos de certificação. Ele deve, não obstante, assegurar que os professores que ele certifica detenham uma competência disciplinar.

7. Assim como foi no início do vigésimo século, o famoso relatório Flexner sobre a formação médica nos Estados Unidos e Canadá (1910).

8. Por exemplo, o sistema educativo americano é percebido nesse relatório como "estando erodido por uma crescente onda de mediocridade que ameaça nosso futuro como nação e como povo" (1983, p. 5). O relatório também afirma que "se um poder estrangeiro não amigável tivesse tentado impor à America o desempenho educacional medíocre que existe hoje, poderíamos ter visto isto como um ato de guerra. Do jeito que está, permitimos que isto aconteça a nós mesmos. Nós temos, de fato, cometido um ato de desarmamento educacional impensável” (1983, p. 5).

9. Parece que o Presidente Reagan tenha tido vontade de abolir esse departamento federal que ele julgava inútil, mesmo contrário ao espírito da constituição americana, a educação sendo de responsabilidade dos estados e das autoridades locais. Portanto, o sucesso mediático do relatório Uma Nação em Risco, bem como a dominância democrata no Congresso, impediramlhe de atuar neste sentido.

10. Este último teria contribuído de maneira significativa à escritura do relatório. Podemos pensar que a forte presença de universitários disciplinares (incluindo os presidentes universitários) na comissão explica em parte a vontade do relatório de "puxar o high school americano para cima", isto é, de acrescentar as exigências e a qualidade em grande parte em função das necessidades do ensino superior.

11. Em anunciando a criação da comissão, o secretário Bell declara que estava preocupado com "a vasta percepção pública de que algo está seriamente descuidado no nosso sistema educacional”.

12. De fato, devemos ser críticos frente a esse discurso sobre a penúria: o sistema escolar americano perde uma boa parte dos seus recrutas porque a inserção profissional está pouco enquadrada e difícil: por exemplo, muitos jovens professores encontram-se nas escolas e nas classes difíceis, das quais os professores mais experientes fogem. De acordo com certos dados, para quatro professores que se inscrevem na formação de professores, somente um sobreviverá o período de inserção (depois de cinco anos). Se esta fosse organizada de modo diferente, a penúria provavelmente seria menor. 
13. Podemos pensar que J. Lanier, membro do grupo de trabalho da Fundação Carnegie e figura central do coletivo de decanos participando do Grupo Holmes, foi um “intermediário”importante entre os dois grupos e contribuiu para a sinergia das agendas de reforma.

14. Para apresentar um quadro completo das ideologias que se afrontam, uma terceira corrente deveria ser apresentada: é a que coloca a ênfase sobre a liberdade de escolha da escola pelos pais, a concorrência entre estabelecimentos e a imputabilidade e a prestação de contas, resumidamente, as investidas em educação da "Nova Gestão Pública". Nem Uma Nação em Risco nem Uma Nação Preparada são inspirados diretamente por este tipo de discurso, bem que este não seja compatível com o discurso de $A$ Nação em Risco. Por outro lado, ele bate de frente com a agenda da profissionalização, substituindo o controle por parte da profissão pela regulamentação do mercado educativo.

15. Notadamente pelo Secretário de Educação americano, no seu relatório sobre a qualidade do ensino (2002), R. Paige propõe de tornar os programas das faculdades de educação não obrigatórios para ter acesso ao ensino público e afirma que os programas alternativos constituem a via do futuro.

16. O que não o impede de se referir ao estudo de Coleman (1966) demonstrando a importância da habilidade verbal.

17. Mais que um combate, no sentido que Bourdoncle (2001) dava a este termo se referindo ao contexto francês.

\section{Referências}

BOURDONCLE, R. La carte de la pensée et le champ du débat [A carta do pensamento e o campo do debate]. Revue Française de Pédagogie, Lyon (France), n. 135, p. 61-64, 2001.

CARNEGIE FORUM ON EDUCATION AND THE ECONOMY. A Nation Prepared: Teachers for the 21st Century, The Report of the Task Force on Teaching as A Profession [Uma nação preparada: professores para o século 21 , relatório da força tarefa sobre o ensino como profissão]. 4éd. New York, 1986.

COALITION FOR EVIDENCE-BASED POLICY. Bringing Evidence-Driven Progress to Education: A Recommended Strategy for the U.S. Department of Education [Trazendo o progresso movido pela evidência à educação: uma estratégia recomendada para o Departamento de Educação dos Estados Unidos da América]. Disponível em: <www.excelgov.org/performance/evidence/ execsumm.htm>. 2002.

COCHRAN-SMITH, M.; FRIES, M. K. Sticks, Stones, and Ideology: the Discourse of Reform in Teacher Education [Gravetos, pedras e ideologia: o discurso da reforma na educação de professores]. Educational Researcher, Thousand Oaks (USA), v. 30, n. 8, p. 3-15, nov. 2001.

COLEMAN, J. S. et al. Equality of Educational Opportunity [Igualdade de oportunidade educacional. Washington, D.C.: U.S. Government Printing Office, 1966.

DARLING-HAMMOND, L. Teacher Quality and Student Achievement: A Review of State Policy Evidence [Qualidade de professor e desempenho de aluno: uma revisão de evidência da política do Estado]. Education Policy Analysis Archives, Tempe (USA), v. 8, n. 1, 2000. 
Research and Rhetoric on Teacher Certification: A Response to «Teacher Certification Reconsidered" [Pesquisa e retórica sobre certificação de professores: uma resposta à "Certificação de professores reconsiderada”]. Education Policy Analysis Archives, Tempe (USA), v. 10, n. 36, 52 p., 2002.

; CHUNG, R. F. Frelow Variation in Teacher Preparation, How Well Do Different Pathways Prepare Teachers to Teach? [Variação na preparação de professores, como diferentes caminhos preparam bem professores para ensinar?]. Journal of Teacher Education, Washington (USA), v. 53, n. 4, p. 286-302, 2002.

DAVIES, P. T. What is evidence-based education? [O que é educação baseada na evidência]. British Journal of Educational Studies, Windsor (UK), v. 47, n. 2, p. 108-121, 1999.

DE BROUCKER, P.; SWEETMAN, A. Towards Evidence-Based Policy for Canadian Education, Vers des politiques canadiennes d'éducation fondées sur la recherche [Em direção à política baseada na evidência para a educação canadense]. Montréal et Kingston: John Deutsch Institute for The Study of Economic Policy, Queen's University et Statistique Canada. McGill-Queen's University Press, 2002.

EDUCATION COMMISSION OF THE STATES. Pros and Cons. Quality Teaching. Two Paths to Quality Teaching: Implications For Policymakers [Pros e contras. Qualidade de professores. Dois caminhos para a qualidade no ensino: implicações para formuladores de políticas]. Disponível em: <www.ecs.org>. 2000.

FEISTRITZER, C. E. Alternatives Teacher Certification. A State by State Analysis [Alternativas para a certificação de professores. Uma análise Estado por Estado]. Washington, D.C.: National Center for Education Information, 2004.

FINN, C. E. Teacher Reform Gone Astray [A reforma dos professores foi à deriva], In: PETERSON, P. E. (Ed.). Our Schools and Our Future... Are We Still at Risk? [Nossas escolas e nosso futuro... Estamos ainda em risco?]. Stanford: Hoover Institution Press, Publication n. 516, 2003. p. 211-238.

FLEXNER, A. Medical Education in the United States and Canada [Educação médica nos Estados Unidos da América e Canadá]. Carnegie Forum on Education and The Economy. Bulletin n. 4. 1910 .

FORDHAM FOUNDATION. The Teachers We Need and How To Get More of Them: A Manifesto [Os professores que precisamos e como termos mais deles: um manifesto]. Jersey City, NJ: Thomas B. Fordham Foundation, 1999.

FRASER, J. W. A Tenuous Hold [Uma sustentação tênue]. Education Next, Stanford (USA), v. 2, n. 1, p. 16-21, 2002.

GOLDHABER, D. The Mystery of Good Teaching [O mistério do bom ensino]. Education Next, Stanford (USA), v. 2, n. 1, p. 50-55, 2002.

HESS, F. M. Tear Down this Wall, the Case for a Radical Overhaul of Teacher Certification [Derrube esta parede, o caso para uma radical revisão da certificação de professores]. Progressive Policy Institute, 21st Century School Project, 2001. 
HITE, S. J. Reviewing Quantitative Research to Inform Educational Policy Processes [Revisando a pesquisa quantitativa para informar os processos de politica educacional. Paris: Unesco - Institute for Educational Planning, 2001.

LACZKO-KERR, I.; BERLINER, D. C. The Effectiveness of «Teach for America» and other Under-certified Teachers on Student Academic Achievement: A Case of Harmful Public Policy [A efetividade de "ensinar para a América" e outros professores subcertificados sobre o desempenho acadêmico de alunos: um caso de política pública danosa]. Education Policy Analysis Archives, Tempe (USA), v. 10, n. 37, 57 p. 2002.

NATIONAL COMMITTEE ON EXCELLENCE IN EDUCATION. A Nation at Risk [Uma nação em risco]. Washington, D.C.: U.S. Department of Education - Excellence Commission, 1983.

NATIONAL COMMISSION ON TEACHING AND AMERICA'S FUTURE. What Matters Most: Teaching for America's Future [ $O$ que importa mais: ensinando para o futuro da América]. New York: NCTAF, 1996.

PAQUAY, L. Vers un référentiel de compétences professionnelles de l'enseignant ? [Em direção a um referencial de competências profissionais do professor?] Recherche et Formation, Lyon (France), n. 16, p. 7-38, 1994.

RAVITCH, D. A Historic Document [Um documento histórico]. In: PETERSON, P. E. (Ed.). Our Schools and Our Future... Are We Still at Risk? [Nossas escolas e nosso futuro... Estamos ainda em risco?] Stanford: Hoover Institution. Publication n. 516, 2003. p. 25-38.

U.S. DEPARTMENT OF EDUCATION. Meeting the Highly Qualified Teachers Challenge. The Secretary's Annual Report on Teacher Quality [Encontrando o desafio do professor altamente qualificado. O Relatório Anual do Secretário sobre Qualidade de Professores]. Washington, D.C.: Office of Postsecondary Education, 2002.

Identifying and Implementing Educational Practices Supported By Rigorous Evidence: A User Friendly Guide [Identificando e implementando práticas educacionais apoiadas em evidência rigorosa: um guia de uso amigável]. Washington, D.C.: Institute of Education Sciences - National Center for Education Evaluation and Regional Assistance, 2003.

WALSH, K. Teacher Certification Reconsidered: Stumbling for Quality [Certificação de professores reconsiderada: tateando por qualidade]. The Abell Foundation, 2001.

Positive Spin, the Evidence for Traditional Teacher Certification Reexamined [Rodopio positivo, a evidência para o reexame da certificação tradicional de professores]. Education Week, Bethesda (USA), v. 21, p. 79-84, 2002. 


\section{Lessard}

\section{The American debate on the certification of teachers and the trap of an educational policy "based on evidence"}

Abstract

The article analyses the lively debate, currently taking place in the United States of America, with respect to the certification of teachers at primary and secondary level, which opposes the "professionalists" and the "deregulationists". This debate is, at the same time, ideological, political and scientific: to begin with, the protagonists are presented with the agendas they adopt and the context of concurrency among the groups interested in the control of the American educational policy; then, the data available and debated are identified, as well as the zones of consensus and of discussion, along with the strategies of argumentation used to try to win the "adversary" and thus be "victorious". Finally, in conclusion, the characteristics of the debate are reflected upon, namely with reference to the "policy based on evidence" and to the relations it reveals between science, politics and ideology.

Keywords: Certification. Deregulation. Teacher training. Public policies. Professionalisation of teaching. University.

\section{Le débat américain sur la certification des enseignants et le piège d'une politique éducative « evidence-based »}

Résumé

On analyse le vif débat, présentement en cours aux États-Unis, à propos de la certification des enseignants du primaire et du secondaire, qui oppose les "professionnalistes " et les "déréglementationistes ". Ce débat est, à la fois, idéologique, politique et scientifique: dans un premier temps, on présente les protagonistes, les agendas qu'ils épousent et le contexte de concurrence entre les groupes intéressés pour le contrôle de la politique éducative américaine; dans un second temps, on identifie les données disponibles et débattues, les zones de consensus et de discussion, ainsi que les stratégies d'argumentation utilisées pour tenter de vaincre l'" adversaire " et de "remporter la victoire ". Enfin, en conclusion, on réfléchi sur les caractéristiques du débat, notamment sur la référence à l'" evidence-based policy " et sur les rapports qu'elle révèle entre la science, la politique et l'idéologie.

Mots clefs : Certification. Déréglementation. Formation de maître. Politiques publiques. Professionnalisation de l'enseignement. Université.

\section{El debate americano sobre la certificación de los profesores y la trampa de una política educativa "basada en la evidencia"} Resumen

Se analiza el debate actual en los Estados Unidos con respecto a la certificación de los profesores de la enseñanza primaria y secundaria, que opone los "profesionalistas" y los "desregulamentacionistas". Este debate es, a un tiempo, ideológico, politico y cientifico. En un primer momento, se presentan los protagonistas, las agendas que adoptan, y el contexto de concurrencia entre los grupos interesados en el control de la politica educativa americana; en un segundo momento, se identifican los datos disponibles y debatidos, las zonas de consenso y de discusión, bien como las estrategias de argumentación utilizadas para intentar vencer el "adversario" y "ser victorioso". Por fin, se reflexiona acerca de las características del debate, principalmente sobre la referencia a "politica basada en evidencias" y las interrelaciones que esta revela entre ciencia, política e ideología.

Palabras-clave: Certificación. Desregulamentación. Formación del profesor. Politicas públicas. Profesionalización de la enseñanza. Universidad.

Recebido em: 05.07.2008

Aceito em: 19.03.2009 